Фернандо Магро, Паоло Ажіончетті, Рамі Еліакім, Сандро Арліззоне, Алессандро Армуцці, Мануель Баррейро-ле-Акоста, Йохан Буріш, Кристина Б. Геше, Аілса ^. Харт, Пітер Хіндрикс, КорА ^ангнер, Ажиммі К. АімАі, Жанлука Пемліно, ЕАіта Загорович, Тім Райне, Маркус ХарборА, Флоріан Рілер

\title{
Третій Європейський доказовий Консенсус з діагностики та лікування виразкового коліту*(продовження)**
}

\section{ЧАСТИНА 3}

\section{Розділ 9. Хірургічне лікування}

\section{1. загальна інформація}

У цьому розАілі піАсумовані рекоменАації ЕССО щоАо хірургічного Аікування пацієнтів з виразковим колітом (ВК). САіА зазначити, що рівень Аоказовості цих хірургічних настанов Аосить скромний, оскі^ьки в Аітературі Аосі віАсутні наАійні АОкази, отримані в результаті провеАених РанАОМізованих АОсліАжень.

Методи оперативних втручань при виразковому коліті були оптимізовані з метою піАвищення якості життя пацієнтів, що потребували провеАення колектомії. Ао початку 1980-х років, за винятком ПоОАИноКИх випаАКів формування ілеоанального анастомозу, золотим станАартом хірургії вважали проктоколектомію та ілеостомію. Постійна ілеостомія за Коком була вперше проведена наприкінці 1960-х років, але не отримала широкого використання, незважаючи на очевиАні дані про те, що якість життя таких пацієнтів, порівняно з проктоколектомією з формуванням звичайної стоми, була значно кращою. За останні 20 років новим золотим станАартом хірургічного втручання стала реконструктивна проктоколектомія з формуванням ілеоанального резервуара (або анастомозу) (IPAA), що зберігає цілісність контурів тіла (оскільки створення стоми не потрібне) та зберігає анальний шлях Аефекації. Втім, за такого метоАу не вАवється віАНовити Функції кишечника, і, таким чином,

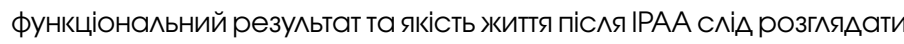
у порівнянні з пацієнтами, яким було провеАено ілеостомію.

\section{2. Технічні питання}

\subsection{1. Хірургічне втручання при гострому тяжкому коліті}

\section{Положення ЕCCO 9A}

Зволікання $з$ проведенням хірургічного втручання може призводити до збільшення ризику розвитку післяопераційних ускладнень (EL4). У випадках гострого коліту (EL 4) у пацієнтів, що приймають > 20 мг преднізолону на добу протягом більше ніж 6 тижнів, або у пацієнтів, що отримують анти-TNF препарати (EL3), рекомендоване проведення багатоетапної операції, що починається з субтотальної колектомії. За наявності у хірурга досвіду проведення лапароскопічних хірургічних втручань, перевага надається лапароскопічним методам втручання (EL3)

А^я безпечного веАення пацієнтів з тяжким перебігом гострого коліту необхіАне залучення як АосвіАчених хірургів, так і гастро- ентерологів. Хоча у багатьох випалках медикаментозна терапія $€$ ефективною, існують переконливі Аокази того, що зволікання 3 провеАенням віАповіАного хірургічного втручання призвоАить АО негативних насліАків. Поетапну проктоколектомію (з початковим провеАенням субтотальної колектомії) вважають оптимальним першим кроком у хірургічному Аікуванні гострого виразкового коліту з тяжким перебігом, а також у пацієнтів, що тривалий час приймають кортикостероїАи (більше 20 мг преАнізолону на Аобу протягом 6 тижнів і Аовше). Субтотальна колектомія з формуванням тимчасової ілеостоми АОзволяє значно полегшити тяжкий стан пацієнта з колітом.

Як результат, така операція приводить АО віАновлення сил, нормалізує харчування та Аає пацієнту час розглянути питання щоАО провеАення поАальшої IPAА або формування постійної ілеостоми. ПопереАня субтотальна колектомія АОзволяє уточнити етіологію патологічного процесу та викАючити хворобу Крона. Субтотальна колектомія $€$ віАносно безпечним метоАом, який можна застосовувати навіть у хворих у критичному стані. ЗгіАно з результатами нещоАавніх СИстематизованих ОГАЯАів, провеАення ^апароскопічних та віАКритих колектомій при нетоксичному коліті супровоАжується Меншою кі^ькістю таких уск^аАнень як інфекція ран та інтраабломінальні абсцеси, а також коротшим періодом госпіталізації. Сучасні докази піАтверАжують, що це ж саме стосується й колектомій при невіАК^аАних станах

\subsection{2. Залишкові Аілянки прямої кишки: хірургічна тактика}

При проведенні субтотальної колектомії зі збереженням частини прямої кишки необхіАно враховувати Аеякі критичні аспекти. Майже повна резекція прямої кишки (наприк^аА перетинання середніх віААілів прямої кишки в межах таза) не рекоменАУЄтьСЯ, ОсКіАьКИ такИЙ ПіАХіА прИзвеАе АО трУАНОщів при поАальшій проктектомії та, вірогіАно, піАвищить ризик травмування тазового нерва. Альтернативою може бути перетинання прямої кишки на рівні крижового мису (тобто у місці ректосигмополібного переходу), або збереження Аистального віААілу сигмоподібної кишки. Це АОзволяє зафіксувати кишку Ао переАньої черевної стінки, що у майбутньому полегшить визначення місцезнаходження кишки та її резекцію, або її переміщення

\footnotetext{
* ECCO Guideline/Consensus Paper Third European Evidence-based Consensus on Diagnosis and Management of Ulcerative Colitis. Part 1: Definitions, Diagnosis, Extra-intestinal Manifestations, Pregnancy, Cancer Surveillance, Surgery, and lleo-anal Pouch Disorders // Journal of Crohn's and Colitis. - 2017. - P. 649-670. DOI: 10.1093 /ecco-jcc/iix008.

** Продовження, початок читайте у попередніх номерах журналу Ліки України № 5-6, (221-222), № 7 (223).
} 
через фасцію черевної стінки із закриттям у піАшкірній жировій кАітковині або вивеАенням У вигляАі фістули. Останній метоА вважають найбезпечнішим, оскільки зашита кишка не залишається у черевній порожнині. ОАнак наявність слизової фістули призвоАИть АО ПОЯвИ АОАТТКОВої СТОМИ, що спричиняє пацієнту АОАатковий Аискомфорт. Ушивання кукси та фіксація її у піАшкірній клітковині також $є$ безпечним методом, але шкірі в такому випаАКу необхіАний час А^я загоєння вторинним натягом, щоб уникнути розвитку ранової інфекції. Наразі невіАомо про провеАення АОсліАжень, які б вивчали ризик виникнення запалення або кровотечі після збереження різної Аовжини Аілянок прямої кишки або ректосигмопоАібного віААіАу товстої кишки. При розтині прямої кишки у черевній порожнині на рівні крижового мису рекоменАується на кілька Анів встановити трансанальний Аренаж Аля запобігання неспроможності швів кукси прямої кишки через накопичення слизу.

9.2.3. Аокалізація анастомозу при реконструктивній проктоколектомії

\section{Положення ЕССО 9В}

При формуванні анастомозу максимальна довжина слизової оболонки аноректальної ділянки між зубчастою лінією та анастомозом не повинна перевищувати 2 см (EL 4)

Поширеним усклаАненням унасліАОк нак^аАання скобкових швів піА час формування і^еоанального анастомозу є розміщення залишків слизової оболонки прямої кишки вище зубчастої ^інії. Це може стати причиною постійного запального процесу в Аі^янHці м'язової манжетки, призвести Ао Аисфункції сформованого резервуара або розвитку Аисплазії чи, Ауже ріАКо, злоякісних новоутворень. Якісно створений із застосуванням скоб низький анастомоз забезпечує кращі насліАКи, АОзволяє уникнути нетримання калу, просочування фекалій внасліАок неспроможності швів анастомозу та знімає обмеження соціальної активності пацієнта.

Аолаткову інформацію про техніку формування анастомозу та місце його розташування у випаАку неоплазії, що усклаАнює коліт, можна знайти в АоАаткових матеріалах, що Аоступні на ЕССО-ЈСС ОН^айН.

\subsection{4. Роль Формування ілеостоми при реконструктивній} проктоколектомії

\section{Положення ЕССО 9C}

При проведенні реконструктивної проктоколектомії з приводу виразкового коліту зазвичай рекомендується накладання петльової ілеостоми (EL3)

ОАним з основних усклаАнень при IPAА є протікання по лінії шва анастомозу або резервуара. Це усклаАнення неріАКо $€$ причиною негативних кАінічних та функціональних насліАків операції. Можливість уникнення насліАків протікання шляхом формування петльової ілеостомії Аосі залишається преАметом Аискусії. Втім, згіАно з останніми Ааними, припинення функціонування Аистального анастомозу може значно знизити частоту протікання. ОАнак неріАко піА час формування резервуара виявляється, що вірогіАні ускАаАнення внасліАОК формування стоми не виправАовують її використання (наприк^аА, у випаАку товстої черевної стінки або через короткі брижі), при цьому нак^аАання анастомозу пройшло успішно.
9.2.5. Кімькість процеАур, необхіАна Амя піАтримання якості мікування

\section{Положення ECCO 9D}

Формування резервуарів має проводитись у спеціалізованих медичних закладах. Великі медичні центри забезпечують нижчий рівень частоти розвитку ускладнень і вищі показники збереження резервуарів після вилікуваних ускладнень (EL 4))

Аоведено, що установи, в яких проводиться велика кількість ск^аАних хірургічних втручань, що потребують спеціального периоперційного наглялу та лікування, мають кращі показники і результати, що також піАтверАжено і Аля хірургії анастомозів. Крім того, великі установи мають більш ефективні піАхоАИ щоАо лікування небажаних побічних станів, що призвоАить Ао кращого виживання резервуарів у випаАку розвитку усклаАень. Таким чином, за можливості, Аоречно провоАити операції з нак^аАання ілеоанального анастомозу у великих спеціалізованих меАичних заклаАах. Точне визначення "великого спеціалізованого меАичного зак^аАу" залишається преАметом суперечок.

9.2.6. Операція з привоАу усклаАнень, пов'язаних з Формуванням ілеоанального резервуара

Негативні показники оперативного лікування при IPAА ск^аАають близько $15 \%$. ПіА поняттям негативні показники розуміють неможливість ліквіАувати ілеостоми протягом невизначеного періоду, незалежно віА резекції резервуара. Зазвичай причинами невАачі $€$ септичні усклаАнення або стійка Аисфункція резервуаpa, хоча інколи причиною може бути помилковий Аіагноз - нерозпізнана хвороба Крона з утворенням фістули або рефрактерне запалення резервуара.

ПереА прийняттям рішення про неуспішність формування резервуара сліА визначити характер необхіАного хірургічного втручання (корегуюча процеАура або реконструкція резервуара). Таке втручання має проводити хірург-колопроктолог, що має спеціальний АосвіА у цій галузі, також повинні бути враховані Аумка пацієнта і його вибір. Вважають, що за результатами проведення операцій, пов'язаних з порушенням ілеоанального резервуара, зберегти резервуар вАається більше ніж у 5,0 \% випаАКів з прийнятними функціональними насліАКами. Так само, як і при хірургічних втручаннях з формування резервуара, операції зі збереження резервуара повинні проводитися у спеціалізованих віАліленнях, Ае значна кілкість таких операцій проводиться регулярно, хоча визначення поняття значної кількості залишається предметом дебатів.

\section{3 Подальше спостереження}

9.3.1. Загальне спостереження за ілеоанальним резервуаром

\section{Положення ЕССО $9 \mathrm{E}$}

У разі виникнення симптомів дисфункції резервуара рекомендоване проведення негайної ендоскопії резервуара, що має на меті розрізнити запалення резервуара та інші ускладнення (EL 4)

Після провеАення IPAA у Аеяких пацієнтів можуть виникати ознаки та симптоми запалення ілеоанального резервуара (виникають у близько 50 \% пацієнтів протягом 10 років спостереження) або ж інших усклаАнень і станів (синаром полразненого ілеоанального резервуара, хвороба Крона у резервуарі, ішемія резервуара, цитомегаловірусна або С. Difficile інфекція). Частота к^і- 
нічних обстежень змінюється залежно віА розвитку цих станів, і на СьогонНі не існує станАартних РекоменАацій щоАО їх частоти. У пацієнтів із симптомами запалення резервуара (ріАкі випорожнення, термінові позиви, тенезми, Аискомфорт у Аілянці таза, порушення балансу електролітів), необхіАно провоАити енАоскопічне АосліАження резервуара щоб віАрізнити його запалення віА інших станів, перерахованих вище. Строки проведення поАальНОГО еНАОСКОПічНОГО НагАЯАУ залеЖать ВіА СтанУ і ПОтреб КОЖНОГО пацієнта.

9.3.2. ПоАальше спостереження за ілеоанальним резервуаром

\section{Положення ECCO $9 F$}

Рекомендоване проведення щорічної ендоскопії ілеоанального резервуара у пацієнтів з факторами ризику, такими як неоплазія та первинний склерозуючий холангіт. У пацієнтів, що не мають симптомів дифункції резервуара, ніяких специфічних вимог до протоколу спостереження за резервуаром немає (EL 3)

Системний огАяА Ааних щоАО Аисп^азії після провеАеної реконструктивної проктоколектомії засвіАчив рівень поширеності 0,15 (Аіапазон: 0-4,49), 0,98 (Аіапазон: 0-15,62) і 1,23 (Аіапазон: 0-25,28 віАсотка) А^я АВС, АНС, і невизначеної Аисплазії, віАповіАно. Аисп^азія оАнаково часто виникала в резервуарі і в ректальній манжеті або в анальній перехіАній зоні. Аисплазія та рак, виявлені Ао або піА час операції, є важливими прогностичними факторами розвитку Аисплазії в резервуарі. Аані цього системного огляАу були піАтверАжені іншими, із зазначенням, що навіть якщо показанням А^я колектомії була Аисплазія або рак, ризик розвитку Аисплазії в ректальній манжеті або ілеоанальному резервуарі залишається Ауже низьким. Тому після провеАення реконструктивної проктоколектомії і при віАсутності інших факторів ризику проведення спеціальних заходів спостереження не є обовязковим.

9.4. РепроАуктивні Функції та пологи у пацієнтів з реконструктивною проктоколектомією.

9.4.1. Вплив операцій на органах малого таза на репродуктивну Функцію

Положення ECCO 9G
У жінок репродуктивного віку слід розглянути альтернативні види оперативних
втручань, такі як субтотальна колектомія або одностовбурова ілеостомія, або
ілеоректальний анастомоз; ці варіанти слід обговорити із пацієнткою, оскільки
реконструктивна проктоколектомія може негативно вплинути на здатність до
дітонародження (EL3). Лапароскопічні методи хірургічних втручань краще
зберігають репродуктивну функцію у жінок і тому повинні бути застосовані
при можливості

Активний перебіг ВК супровоАжується погіршенням сексуальної функції. Результати Авох проспективних АосліАжень продемонстрували покращення сексуальної функції у пацієнтів обох статей протягом 12 місяців після IPAA порівняно з переАопераційними показниками. 3 іншого боку, переконливі результати трьох АосліАжень когорти свіАчать про зниження репроАуктивної функції у жінок після провеАення IPAА. НайвірогіАнішою причиною такого зниження вважають утворення спайок, які вражають фамлопієві труби. Серйозність цієї проблеми є предметом Аискусій; так, результати оАного АОсліАження вказують на зниження репроАуктивної функції більше ніж на $70 \%$, тоАі як результати інших свіАчать про зниження репродуктивної функції лише на $30 \%$. Збільшується кільксть Ааних про те, що ^апароскопічна IPAA $€$ технічно можли- вою, і що вона може зменшити негативні насліАКи А^я жіночої репроАуктивної функції.

У хоАі АОсліАЖення за участі пацієнтів із роАинним аАеноматозним поліпозом було проведене порівняння зниження репроАуктивної функціїі у жінок із сформованим ілеоректальним анастомозом (IRA) та жінок після IPAA, і отримано Аокази того, що IRA не викликає зниження репроАуктивної функції. Причиною цього, як ввважають, є те, що IRA не спричиняє утворення тазових спайок у такій кількості, як IPAA. Окрім того, існують Аокази, що IRA $€$ безпечнішим втручанням і забезпечує більш сприятливі функціональні насліАКИ.

У пацієнтів чоловічої статі основними, проте такими, що ріАко трап^яються, уск^аАненнями IPAА, які призвоАять АО порушень сексуальної та репроАуктивної функцій, є ретрограАна еякуляція та еректильна Аисфункція. Обох цих усклаАнень можна уникнути при провеАенні IRA. ПіА час прийняття рішення щоАО вибору типу хірургічного втручання, питання створення IRA має бути розгАянуте (Аив. розАі^ 9.5.3.).

Інформацію про спосіб пологів у пацієнтів з реконструктивною проктоколектомією можна знайти в Аодаткових матеріалах, АОступних на ЕССО-ЈСС он^айн.

\section{5 Вибір типу операції, окрім реконструктивної прокто- колектомії}

\subsection{1. Вік}

\section{Положення ЕССО 9H}

Для проведення реконструктивної проктоколектомії з формуванням ілеоанального резервуара вікових обмежень не існує. Необхідною умовою $є$ збереження у пацієнтів функції сфінктера (EL 5)

IPAA може спричиняти піАвищення ризику супутніх захворювань у пацієнтів віком старше 65 років. Незважаючи на це, операція у цій віковій групі вважається безпечною та ефективною і залишається оАнією з операцій вибору. ВіАомо про піАвищену частоту виникнення усклаАнень у Аовготривалій перспективі (наприклаА, запалення резервуара, стриктура анастомозу) піА час провеАення IPAА у пацієнтів похилого віку. 3 часом спостерігається зниження функціонального стану резервуара та погіршення утримувальної зАатності, особливо це стосується пацієнтів похилого віку. Втім, у пацієнтів віком старше 65 років, яким була проведена ІРАА, зберігається задовільна якість життя.

\subsection{2. Континентна ілеостомія}

І^еостома за Коком є альтернативою звичайній кінцевій ілеостомії після невАалої IPAА та у пацієнтів, яким провеАення IPAA протипоказане (наприклаА при травмі сфінктера), а також у випаАках, коли ілеостома викликає серйозні проблеми (наприк^аА протікання, ураження шкіри тощо).

Багато хірургів вважають операцію ілеостомії за Коком АискреАитованою через піАвищений рівень необхіАності повторної операції, оскільки приблизно половина пацієнтів буде потребувати повторних операцій, при цьому найпоширенішим показанням АО цього Є зміщення К^апана. ОАнак на сьогоАні більшість Ааних свіАчить про частоту 10-річного виживання континентного резервуара на рівні $90 \%$. Якість життя пацієнтів з резервуаром за Коком вища, ніж при кінцевій ілеостомі. ЗгіАно з Ааними АосліАження 
КАініки КАівленАа, пацієнти з кінцевою ілеостомою більш ніж уАвічі частіше скаржились на соціальні, робочі та сексуальні обмеження, ніж ті, у кого була сформована континентна ілеостома за Коком.

\subsection{3. І^еоректальний анастомоз}

Положення ЕССО 9I
За оптимальних обставин ілеоректальний анастомоз є розумною альтернати-
вою ілеоанальному резервуару (EL5). Однак його переваги, до яких належать
нижча частота ускладнень та збереження репродуктивної функції у жінок,
повинні бути зважені і оцінені у порівнянні з необхідністю ректального спо-
стереження та наступної протектомії в $50 \%$ випадків (EL3)

Небажання багатьох хірургів проводити операції за IRA при ВK пов' язане з тим, що після IPAА спостерігається кращий Аовготривалий функцональний стан резервуара, порівняно з непереАбачуваним функціональним станом піс^я IRA при пошкоАженій і запаленій прямій кишці, а також з побоюванням наступного розвитку раку прямої кишки. IRA $€$ менш ск^аАною операцією з меншою частотою усклаАнень, що Аає хороші кАінічні результати у ретельно віАібраних пацієнтів. Пацієнти, яким показане проведення IRA, повинні мати віАносно збережену слизову оболонку прямої кишки (або ж загоєну слизову оболонку прямої кишки внасліАок меАикаментозної терапії), хорошу функцію прямої кишки, нормальний тонус сфінктера. У таких пацієнтів дефекація віАбувається майже так само, як і у пацієнтів після IPAА втручання, хоча, згіАно з Ааними публікацій, термінові позиви частіше виникають при IRA (22-33 \%). Термінові Аефекації є найчастішим проявом невАа^ого IRA. ПовіАом^яється, що очікувана частота функціону-

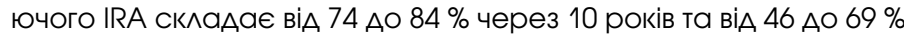
через 20 років після проведення операції. НеобхіАним є періодичне спостереження за станом залишкових Аілянок прямої кишки.

9.5.4. Аисфункція резервуара незапальної етіології та неспроможність резервуара

\section{Положення ЕССО 9J \\ Незапальні причини дисфункції резервуара включають резервуарно-анальні стриктури, фістули резервуара, проблеми з ємністю резервуара, дисфункцію еферентного кінця (S-резервуар), збереження ректальної кукси, хронічне пресакральне септичне ураження. У прийнятті рішення щодо тактики ведення таких пацієнтів повинні брати участь різні відповідні спеціалісти}

Аетальну інформацію про незапальну Аисфункцію резервуара можна знайти в АоАаткових матеріалах, АОступних на ЕССОJCC Он^айн.

\section{6. МеАикаментозна терапія при хірургічному втручанні \\ 9.6.1. Прийом преАнізолону у періопераційний періоА}

Результати неконтрольованих та ретроспективних АосліАжень свіАчать про існування піАвищеного ризику хірургічних усклаАнень у пацієнтів, які приймають преАнізолон в Аозі більше ніж 20 мг протягом 6 тижнів і більше. Ці АосліАження засвіАчили 5-кратне збільшення ризику інфекційних усклаАнень та піАвищенний ризик короткострокових післяпераційних усклаАнень, пов'язаних 3 резервуаром. Тому прийом стероїАів переА хірургічним втручанням повинен бути припинений. Якщо припинення прийому кортикостероїАів неможливе, тоАі необхіАно віАкласти оперативне втручання з формування резервуара. Всі рекоменаації щоАо ступеня зниження Аози стероїАів після колектомії А^я гострого тяжкого перебігу коліту є Аовільними, але сліА уникати різкої віАміни стероїАів (аАісонова криза), яка в найсерйозному випаАку характеризується розвитком гіпотензії, гіпонатріємії та гіпоглікемії. Більш м'які симптоми можуть трактуватися як повільніший, ніж зазвичай, процес віАновлення після операції. ШвиАкість зменшення АОбової АОзи залежить віА АОзи і тривалості прийому стероїАів, що передували хірургічному втручанню. Пацієнтам, які приймали стероїАи протягом 6 місяців або Аовше, рекоменАується знижувати Аозу кортикостероїАних препаратів по 1 мг на тижАень протягом Аекількох місяців.

9.6.2. Прийом тіопуринів та інгібіторів кальциневрину в переАопераційний періоА

\section{Положення ЕСCO 9K}

Прийом тіопуринів або циклоспорину в передопераційний період не збільшує ризик післяопераційних ускладнень (EL3)

Тіопурини та циклоспорин не піАвищують ризик післяопераційних усклаАнень після колектомії. Інформація щоАО вп^ивУ такролімусу все ще неАостатня.

\subsection{3. Прийом інфАіксимабу у переАопераційний періоА}

TNF $€$ основним компонентом імунної віАповіАі, пригнічення його Aiї внасліАок прийому IFX або інших імуносупресивних препаратів теоретично може призвести Ао серйозних післяопераційних усклаАнень. Значна кількість АосліАжень ризиків післяопераційних усклаАнень, пов'язаних з прийомом IFX, Аемонструє результати, що мають суперечливий характер. Результати оАного з них, метааналізу п'яти АосліАжень за участю 706 пацієнтів, у якому зверта^ась особлива увага на пацієнтів з ВК, продемонстрували, що прийом інфліксимабу у передопераційний періоА піАвищував загальну кількість ранніх (30 Аіб) післяопераційних уск^аАнень (віАношення шансів 1,80, 95 \% Аовірчий інтервал 1,12-2,87). Хоча через неАостатню потужність аналізу похоАження цих усклаАнень оцінити неможАиво, бУло зареєстровано тенАенцію АО піАвищення кількості післяопераційних інфекційних усклаАнень (віАНошення шансів 2,24, 95 \% Аовірчий інтервал 0,63-7,95), тоАі як частота неінфекційних усклаАнень залишалася без змін (віАношення шансів 0,85, 95 \% Аовірчий інтервал 0,50-1,45) у пацієнтів, що отримували IFX в переАопераційний періоА. Результати АосліАжень, опубліковані після цього мета-аналізу, не свіАчать про піАвищену частоту розвитку уск^аАнень після проктоколектомії, пов'язаних 3 прийомом інфліксимабу. Оскільки майже всі Аані були отримані в хоАі обсерваційних, а не ранАомізованих контрольованих АосліАжень, існує ризик системної помилки в результатах. АосліАження, проведене у КАініці Мейо, показало, що такі уск^аднення як неспроможність швів анастомозу, усклаАнення з боку резервуара та інфекційні процеси траплялися частіше у пацієнтів, що отримували IFX у передопераційний періоА, ніж у пацієнтів, які не приймали IFX. Після поправки на Аію супутньої терапії та ступінь тяжкості коліту, прийом IFX був єАиним фактором, незалежно пов' язаним з виникненням інфекційних усклаАнень. Також результати нещоАавно опублікованих АосліАжень показали, що пацієнти, які раніше отримували анти-TNF препарати мали вищу частоту тазового сепсису після оАНофазної IPAА. I навпаки, у великому Аатському реєстрі, що вк^ючав більше ніж 1200 пацієнтів з ВК, яким була проведена проктоколектомія, немає Ааних щодо значного збільшен- 
ня частоти уск^аАнень після хірургічного втручання у пацієнтів, що раніше отримували IFX.

Ступінь тяжкості захворювання та ступінчаста схема прийому цик^оспорину також може піАвищувати післяопераційний ризик уск^аАнень, пов'язаних з прийомом IFX. Прийом інфліксимабу може бути корисним у пацієнтів із захворюванням помірної активності та, віАповіАно, низьким рівнем С-реактивного білка, та особ^иве занепокоєння викликає те, що ургентна колектомія, провеАена через кілька тижнів після прийому інфліксимабу може призвести Ао більшої кількості септичних уск^аАнень.

Результати кількох АосліАжень свіАчать про ефективність та безпечність прийому цик^оспорину та IFX піА час ступінчастої терапії порятунку у пацієнтів з ВК, стійким АО прийому кортикостероїАних препаратів. Майже третина пацієнтів Аосягли ремісії у короткочасний періоА, та майже Аві третини уникли необхіАності проведення колектомії у найближчий термін. Аналогічні спостереження віАмічено у групахпацієнтів, які приймали інфліксимаб після незаАовільних результатів терапії циклоспорином, а також у пацієнтів, які приймали цик^оспорин після незаловільної терапії інфліксимабом. Втім, у 16 \% випалків спостерігалися серйозні небажані явища, сереА них - сепсис з летальним насліАком та герпесвірусний езофагіт. Залежність ризику виникнення інфекційних уск^аАНень віА посліАОвності прийому препаратів не встанов^ена, хоча теоретично прийом IFX після цик^оспорину повинен бути більш безпечним за рахунок того, що циклоспорин має значно коротший періоА напіврозпаАу. Хоча результати Аеяких АосліАжень свіАчать про таку саму частоту виникнення усклаАнень, що й піА час монотерапії IFX або цик^оспорином, сліА уважно аналізувати співвіАношення ризику / користі ступінчастої терапії порятунку, яка може бути застосована лише у Аеяких пацієнтів і не повинна використовуватися рутинно. Особливо це стосується застосування циклоспорину після незаАовіАьних результатів терапії інфліксимабом. Таким чином, поки Аані про періопераційне застосування анти-TNF препаратів залишаються суперечливими, основна рекоменАація вимагає не провоАити оАноетапну проктоколектомію зі створенням ілеоанального резервуара у пацієнтів, які отримують анти-TNF препарати.

\section{Розділ 10. Паучит}

\section{1. Загальна інформація}

Проктоколектомія з ілеоанальним анастомозом (IPAA) $€$ процеАурою вибору Аля більшості пацієнтів з ВК, які потребують колектомії. Паучит $€$ неспецифічним запаленням ілеоального резервуара та найчастішим усклаАненням IPAА у пацієнтів з ВК. Частота його виникнення пов'язана з тривалістю контрольного періоду, Аосягаючи до 50 \% у пацієнтів через 10 років після IPAA. Сукупна частота розвитку паучиту сереА пацієнтів з IPAA, проведеного у випаАках сімейного аАеноматозного поліпозу, $€$ набагато нижчою, і знаходиться у Аіапазоні віА 0 Ао $10 \%$, оАНаК причини вищої частоти розвитку паучиту при ВК залишаються невіАОмими. Більше того, залишається невіАОмим, чи то паучит частіше розвивається протягом перших років після проведення IPAА, чи то ризик продовжує зростати з тривалістю контрольного періоАу.

\section{Положення ECCO 10A}

Встановлення діагнозу «паучит» потребує наявності симптомів разом 3 характерними ендоскопічними та гістологічними ознаками (EL3). Поширений виразковий коліт, первинний склерозуючий холангіт, некурці, позитивні результати серологічного аналізу на р-ANCA та застосування НПЗП є можливими факторами ризику розвитку паучиту (EL3)

\subsection{1. Симптоми}

Після проктоколектомії з ІРАА Аенна меАіанна частота випорожнень склаАає віА 4 Ао 8 актів Аефекації обсягом Ао 700 мл напівсформованих/ріАКих випорожнень на Аобу, порівняно 3 обсягом 200 м^ на АОбу у зАОрових ^юАей. СИмптоми, пов' язані 3 паучитом, вКАючають піАвищену частоту та ріАКий стан випорожнень, спазми в животі, невіАКлаАні позиви, тенезми та Аискомфорт в Аілянці таза. Також можуть виникати такі симптоми як ректальна кровотеча, ^ихоманка або ПКП. ОАнак ректальна кровотеча частіше має віАношення АО запалення ректальної манжети (Аив. РозАіл 10.4), ніж до паучиту. Нетримання калу може виникати і за віАсутності паучиту після IPAA, але частіше трап^яється у пацієнтів з паучитом. Симптоми Аисфункції резервуара у пацієнтів з IPAA можуть бути спричинені іншими станами, в тому числі хворобою Крона резервуара, куфітом при подразненому резервуарі. Саме тому Аіагноз ґрунтуєтьСЯ На енАОСКОПічних та гістологічних Ааних у поєАНанні з СИмптомами.

\subsection{2. ЕнАоскопія ("паучоскопія")}

А^я піАтверАження Аіагнозу пацієнтам із симптомами, що нагаАують паучит, сліА провоАити паучоскопію та біопсію слизової оболонки резервуара. Іноді пацієнти з ілеоанальним резервуаром мають стриктури в резервуарно-анальному анастомозі, отже, Аля провеАення паучоскопії краще обирати гастроскоп, а не КО^оноскоП. ЗавжАИ САіА Намагатися АОсягти просування У аферентний ілеальний сегмент. ЕнАоскопічні Аані, що можуть вказувати на паучит, вк^ючають Аифузну еритему, яка може бути плямистою, на віАміну віА тієї, що спостерігається при ВК. Характерні енАоскопічні Аані також вкАючають набряк, зернистість, крихкість, спонтанну або контактну кровотечу, втрату суАинного малюнка, слизовий ексуАат, крововиливи, ерозії та виразкування. Ерозії та / або виразки взАовж лінії шва не обов'язково $€$ ознаками паучиту. Зразки біопсії сліА брати зі слизової оболонки резервуара та з привіАного сегмента наА резервуаром, але не взАОвж Аінії шва.

\subsection{3. Гістопатологія паучиту}

АоАаткова інформація про гістопатологію паучиту Аоступна в АОАаткових матеріа^ах на ЕССО-ЈСС ОН^айН.

\subsection{4. Аиференційна Аіагностика}

Історія хвороби та біопсія Аопомагають розрізняти паучит, ішемію, хворобу Крона та інші форми Аисфункції резервуара, що ріАКо трап^яються, такі як колагеновий паучит, Clostridium difficile або цитомегаловірусний паучит. Має бути розглянута можливість виникнення вторинного паучиту, спричиненого тазовим сепсисом, який зазвичай викликає фокальне запалення. Зразки біопсії, отримані з віАрізка клубової кишки наА резервуаром, можуть виявити, що переАрезервуарний ілеїт є причиною Аисфункції резервуара, хоча зазвичай він викликає видиме виразкування, яке можна сплутати з хворобою Крона. СліА також розглянути можливість виникнення неспецифічного ілеїту, спричиненого застосуванням НПЗП. 


\subsection{5. Фактори ризику розвитку паучиту та Аисфункції резер-} Byapa

Етіологія паучиту залишається неясною. Фактори ризику, генетичні зв' язки та серологічні маркери паучиту АОзволяють припустити, що тісна взаємоАія між імунною віАповіААю госпоАаря й мікрофлорою резервуара грає віАповіАну роль в етіо^огії цього іАіопатичного запального захворювання. ВіАомі фактори ризику розвитку паучиту включають поширений ВК, ретрограАний ілеїт, ПКП (особливо ПСХ), віАСутність звички АО куріння та регулярне застосування НПЗП. Поліморфізм гена антагоніста рецептора інтерлейкіну-1 та наявність перинуклеарних антинейтрофільних цитоп^азматичних антиті^ рANCAs також асоціюються з паучитом. Не Аивно, що результати АОсліАжень стосовно ролі кожного фактора ризику є суперечливими. У АосліАженні 240 посліАовних пацієнтів були поАілені на тих, що мають зАорові резервуари $(n=49)$, паучит $(n=61)$, хворобу Крона $(n=39)$, куфіт ( $n=41)$ та синАром поАразненого резервуapa $(n=50)$. Ризик розвитку паучиту піАвищувався, якщо показанням АО провеАення IPAА була Аисплазія, якщо пацієнт ніколи не курив, застосовував НПЗП або (можливо) ніколи не приймав анксіолітиків. Ризик діагностування хвороби Крона в резервуарі значно піАвищувався у курців та помірно збільшувався у пацієнтів, які мали резервуар протягом тривалого періоду часу. Куфіт асоціювався з симптомами артралгії та молоАим віком. СИнаром полразненого резервуара ймовірно неАооцінений, хоча $€$ частою причиною Аис функції резервуара у випаАку, коли інші причини (в тому числі невеликий об'єм резервуара, неповна евакуація та заворот резервуара) були виключені, або за результатами аналізів не виявлено віАхилень. Базовим фактором ризику $є$ застосування антилепресантів або анксіолітиків (це АОЗвО^яє ПрИПУСТИТИ, ЩО Ці АЮАИ МОЖУТЬ МОТИ СИНАРОМ ПОАРСЗненого кишечника, що сприяє розвитку симптомів коліту переА операцією на резервуарі). Як і у випаАку синарому полразненого кишечника, у цих пацієнтів була віАзначена вісцеральна гіперчутливість. За Ааними обстеження тієї ж групи пацієнтів нещоАавно виявлено, що переАвісниками паучиту можуть бути різні періопераційні фактори. ПіА час проведення багатофакторного аналізу з паучитом асоціювалися супутнє захворювання ^егень, розташування ураження кишечника проксимальніше селезінкового кута, ПКП, S-резервуарна реконструкція. Ці фактори ризику не повинні перешкоАжати проктоколектомії, якщо хірургічне втручання $є$ Аоречним, але переА операцією сліА обговорити це питання з пацієнтом та його сім' єю. ПоАібним чином, якщо пацієнт стражАає віА ПСХ, Аоречно обговорити високий ризик розвитку паучиту. Такі обговорення $є$ частиною належного повоАження з очікуваннями пацієнтів, а віАомі прогностичні фактори появи паучиту або подразненого резервуара не повинні вважатися формальними протипоказаннями Ао операції на резервуарі.

\section{2. РізновиАи паучиту}

\subsection{1. Гострий та хронічний паучит}

На піАставі симптомів і Ааних енАоскопії паучит можна поАімити на паучит в стаАії ремісії (нормальна активність резервуара) та активний паучит (піАвищена активність за наявності енАОско- пічних та гістологічних ознак паучиту). Активний паучит може бути поАілений на гострий та хронічний, залежно віА тривалості симптомів. Поріг хронічного характеру - це тривалість симптомів протягом періоду понаА 4 тижні. У близько $10 \%$ пацієнтів розвивається хронічний паучит, який потребує тривалого лікування, а у невеликої піАгрупи паучит $€$ рефрактерним Ао консервативного лікування. 3 різних точок зору паучит також можна поАілити на:

1) іАіопатичний та вторинний;

2) у стаАії ремісії та активний;

3) нечастий (<3 епізоАів на рік) та рециАивний ( $>3$ епізодів на pik).

Також паучит можна к^асифікувати на піАставі віАповіАі на лікування антибіотиками:

1) віАповіАає на лікування антибіотиками;

2) залежний віА антибіотиків (необхіАність в постійній антибіотикотерапії а^я піАтримання стаАії ремісії);

3) нечутАивий АО антибіотиків.

Аетальну інформацію про шкалу оцінювання паучиту можна знайти в АОАаткових матеріалах, АОступних на ЕССО-ЈСС Он^айн.

\subsection{2. РециАивний паучит та ускАаАнення}

Паучит рециАивує у більш ніж 50 \% пацієнтів. Пацієнтів з рециАивним паучитом можна поАілити на три категорії: нечасті епізоАи (<1 на рік), рециАивуючий перебіг (1-3 епізоди на рік) або постійний перебіг. Також паучит може бути визнаний таким, що Аає віАповіАь на лікування, або рефрактерним, на піАставі віАповіАі на монотерапію антибіотиками. Хоча ці віАмінності $є$ значною мірою умовними, вони Аопомагають як пацієнтам, так і їх лікарям піА час вибору варіантів лікування з метою впливу на перебіг паучиту. УсклаАнення паучиту включають формування абсцесу, фістули, стенозу резервуарно-анального анастомозу та аАенокарциному резервуара. Останнє усклаАнення є винятковим і трапляеться ^ише за наявності Аисплазії або карциноми в перших зразках колектомії.

\section{3. Консервативне лікування}

\subsection{1. Гострий паучит: антибіотики}

\section{Положення ЕCCO 10B \\ Більшість пацієнтів відповідають на метронідазол чи ципрофлоксацин, хоча оптимальні методи лікування досі не були чітко визначені (EL2). Побічні ефекти трапляються рідше при застосуванні ципрофлоксацину (EL2). Протидіарейні препарати можуть зменшити кількість щоденних рідких випорожнень неза- лежно від наявності паучиту (EL5)}

Аікування паучиту є здебільшого емпіричним, були проведені лише невеликі плацебо-контрольовані випробування. Антибіотики $€$ основою лікування, а метроніАазол і ципрофлоксацин $є$ найпоширенішими препаратами першого вибору, які часто викликають швиАКУ віАПовіАь. ОАнак ранАОмізовані випробування застосування як метроніАазолу, так і ципрофлоксацину, є невеликими.

Порівняння метроніАазолу та ципрофлоксацину провоАилося у невеликому ранАомізованому АосліАженні. Семеро пацієнтів отримували ципрофлоксацин у АОзі 1 г/АОбу, а Аев'ять пацієнтів отримували метроніАазол у АОзі 20 мг/кг/АОбу протягом 2 тижнів. ОбиАва антибіотики значно знизили ІнАекс активності періанального захворювання (Perianal Disease Activity Index (PDAl)), оАнак спостерігався значно виражений позитивний вплив ципрофлок- 
сацину, порівняно з метроніАазолом, на показники PDAI $(p=0,002)$, оцінки симптомів $(p=0,03)$ та енАОскопічної оцінки $(p=0,03)$, а також менша частота небажаних явищ (33 \% пацієнтів, які отримували метроніАазол, повіАомили про появу побічних ефектів, тоАі як пацієнти, які приймали ципрофлоксацин, не повіАомляли про такі ефекти). У лікуванні гострого паучиту (4 ранАомізованих контромьованих АосліАження, 5 лікарських засобів) ципрофлоксацин був більш ефективним в інаукуванні ремісії, ніж метроніАазол. Ані рифаксимін, ані Lactobacillus plantarum GG не були ефективнішими за плацебо, тоді як кАізми з будесоніАом і метроніАазол були оАнаково ефективними в інАукуванні ремісії. У неранАомізованому неконтрольованому віАкритому АосліАженні ефективність лікування активного паучиту зі слабкою активністю продемонстрував висококонцентрований пробіотичний препарат (VSL\#3).

\subsection{2. Хронічний паучит}

\section{Положення ECCO 10C}

При хронічному паучиті ефективною $є$ комбінація двох антибіотиків (ЕLЗ). Альтернативою $є$ пероральний будесонід, пероральний беклометазону дипропіонат (EL3), а також місцева форма такролімусу. Інфліксимаб виявився ефективним у лікуванні хронічного рефрактерного паучиту (EL4). Адалімумаб може бути альтернативою при лікуванні пацієнтів, рефрактерних до інфліксимабу (EL4)

У пацієнтів з персистуючими симптомами сліА розгяянути можливість іншого Аіагнозу. Приблизно у 10-15\% пацієнтів 3 гострим паучитом розвивається хронічний паучит, який може бути таким, що віАповіАає на лікування, або рефрактерним Ао лікування при монотерапії антибіотиком.

Пацієнти з хронічним рефрактерним паучитом не віАповіАають на траАиційну терапію й часто мають тривалі симптоми. Це є частою причиною невАалого функціонування резервуара. В таких випаАках може бути ефективною комбінована антибіотикотерапія або ж прийом буАесоніАу перорально. За результатами нещоАавно провеАених АосліАжень пероральний прийом бек^ометазону Аипропіонату продемонстрував ефективність щоАо Аікування хронічного рефрактерного паучиту. Аесять посліАовних пацієнтів з активним паучитом, які не віАповіАали на терапію антибіотиками протягом 1 місяця, отримували лікування беклометазону Аипропіонатом у Аозі 10 мг/Аобу протягом 8 тижнів. Вісім 3 Аесяти пацієнтів (80\%) Аосягли ремісії.

10.3.3. Гострий та хронічний рефрактерний паучит: інші засоби

Аетальну інформацію про інші препарати А^я лікування гострого і хронічного рефрактерного паучиту можна знайти в Аодаткових матеріалах, що Аоступні на ЕССО-ЈСС он^айн.

\subsection{4. ПіАтримання ремісії: пробіотики}

Після Аосягнення ремісії при хронічному паучиті, Аікування із застосуванням концентрованої пробіотичної суміші VSL\#3 Аопомагає піАтримувати стан ремісії. Ефективність VSL\#3 (450 м^рА бактерій 8 різних штамів/г) у піАтриманні сталії ремісії у пацієнтів з хронічним паучитом була піАтверАжена у Авох поАвійних сліпих плацебо-контрольованих АОсліАженнях. СИстематичний огляА Кокрейна виявив, що VSL\#3 був більш ефективним, ніж п^ацебо, у піАтриманні стану ремісії при хронічному паучиті у пацієнтів, які Аосягли ремісії за Аопомогою антибіотиків.

\subsection{5. Профілактика паучиту: пробіотики}

Той самий пробіотичний препарат (VSL\#3) продемонстрував зАатність запобігати розвитку паучиту протягом першого року після оперативного втручання у ранАомізованому поАвійному сліпому плацебо-контрольованому АосліАженні. У пацієнтів, яких Аікували із застосуванням VSL\#3, була значно нижча частота виникнення гострого паучиту (10\%), ніж у тих, хто отримував п^ацебо (40 \%) (р<0,05), та суттєво покращувалася якість життя. Систематичний огляА Кокрейна повіАОм^яє, що VSL\#3 був більш ефективним, ніж плацебо у запобіганні розвитку паучиту.

\section{4. Куфіт}

Куфіт може спричиняти Аисфункцію резервуара із симптомами, що імітують паучит або синАром подразненого резервуара, особливо після IPAА з поАвіЙним швом (Аив. РозАі^ 9). На віАміну віА Синарому поАразненого резервуара (який також може бути супутнім захворюванням), характерною ознакою куфіту є кровотеча. Аіагноз може бути встановлений за Аопомогою енАоскопічного обстеження, але сліА бути Ауже уважними при обстеженні манжети цилінаричного епітелію між зубчастою лінією та резервуарно-анальним анастомозом (РозАіл 9.2.3). У віАкритому АосліАженні у 14 посліАовних пацієнтів з куфітом, які отримували лікування із застосуванням 5-ASA супозиторіїв 500 мг Авічі на Аобу, спостерігалося зниження загального інАексу активності куфіту

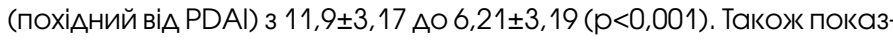

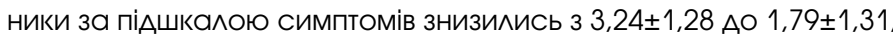

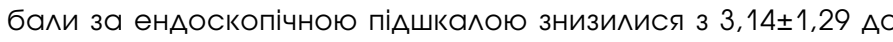

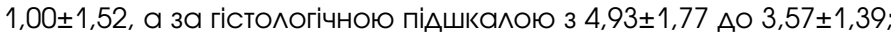
92 \% пацієнтів з кривавими випорожненнями кишечника і 70 \% артралгією (характерною клінічною рисою куфіту) віАзначили покращення в результаті лікування. ПовіАомлень про системні чи місцеві небажані явища отримано не було. 